\title{
КОРЕКЦІЯ ДИСБІОЗУ ТОВСТОЇ КИШКИ ТА Ї̈̈ ВПЛИВ НА ДИНАМІКУ РІВНІВ ВІЛЬНИХ АМІНОКИСЛОТ У СИРОВАТЦІ КРОВІ У ХВОРИХ НА ХРОНІЧНИЙ ПАНКРЕАТИТ ТА ЦУКРОВИЙ ДІАБЕТ 2-ГО ТИПУ
}

\author{
Є.C. Сірчак, В.Є. Барані, З.Й. Фабрі, С.С. Сірчак
}

ДВНЗ «Ужгородський національний університет»; медичний фракультет, кафредра пропедевтики внутрішніх хвороб

Резюме. Дисбіоз товстої кишки (ДТК) часто виникає при захворюваннях травного тракту, зокрема при хронічному панкреатиті (ХП).

Мета дослідження - дослідити есективність різних схем корекції ДТК та ї̈ вплив на динаміку вільних амінокислот сироватки крові (ВАКСК) у хворих на ХП та цукровий діабет (ЦД) 2-го типу.

Матеріали та методи дослідження. Обстежено 82 хворих на ХП та ЦД 2-го типу. Усім обстеженим пацієнтам проведено загальноклінічні дослідження, аналіз калу на дисбіоз, а також визначення рівня ВАКСК. Хворих на ХП та ЦД 2-го типу розподілено на 2 групи залежно від методу корекції ДТК.

Результати та їх обговорення. Призначена терапія виявилась ефективною в обох групах обстежених хворих на ХП та ЦД 2-го типу на вираженість проявів ДТК. Нормалізація мікросрлори товстої кишки у хворих на ХП та ЦД 2-го типу супроводжувалась позитивною динамікою в рівнях ВАКСК. Встановлено зменшення показників метіоніну, валіну, цистеїну в пацієнтів обох досліджуваних груп. Звертає увагу більш виражена позитивна динаміка в рівнях таких амінокислот, як триптосран, тирозин, фенілаланін, аспарагін $(p<0,01)$ переважно у хворих II групи.

Висновки. У хворих на ХП та ЦД 2-го типу встановлено ДТК переважно III та II ступенів, що супроводжується порушенням рівнів ВАКСК у цих пацієнтів. Комплексна терапія із використанням препарату Bacillus coagulans та вітамінів $\mathrm{B}_{9}$ i $\mathrm{B}_{12}$ у поєднанні 3 B. infantis 35624 у хворих на ХП та ЦД 2-го типу $є$ ефективним засобом для нормалізації ДТК, що, у свою чергу, супроводжується позитивною динамікою в рівнях ВАКСК (зменшенням показника метіоніну, валіну, цистеїну та збільшенням рівня триптофрану, тирозину, феенілаланіну).

Ключові слова: хронічний панкреатит, цукровий діабет 2-го типу, дисбіоз, амінокислоти, лікування.

УДК: 616.345-008.87:616.36003.826:616.379-008.64]-08 DOI: 10.31793/2709-7404.2021.2-1.39 (C) Є.С. Сірчак, B.Є. Барані, 3.Й. Фабрі, C.C. Сірчак

\section{Надійшла до редакції 02.03.2021}

Адреса для листування (Correspondence): Івано-Франківський національний медичний університет, вул. Галицька, 2, м. Івано-Франківськ, 76018, Україна.E-mail: zdovado@ukr.net 


\title{
Correction of dysbiosis of the colon and its influence on the dynamics of free amino acids levels in blood serum in patients with chronic pancreatitis and type 2 diabetes
}

Ye.S. Sirchak, V.Ye. Barani, Z.Yo. Fabri, S.S. Sirchak

SHEl «Uzhhorod National University», Department of Propedeutics of Internal Diseases

\begin{abstract}
Introduction. Intestinal dysbiosis (DB) often occurs in diseases of the digestive tract, in particular in chronic pancreatitis (CP). The aim of the study was investigate the effectiveness of various DB correction and its effect on the dynamics of serum free amino acids (SFAA) in patients with CP and type 2 diabetes mellitus (DM). Materials and methods of research. 82 patients with CP and type 2 diabetes were examined. All examined patients underwent general clinical studies, feces for dysbiosis, as well as determination of the level of SFAA. Patients with CP and type 2 diabetes are divided into 2 groups depending on the method of correction of DB. Results and discussion. Prescribed therapy was effective in both groups of examined patients with CP and type 2 diabetes on the severity of DB. Normalization of the intestinal microbiota in patients with CP and type 2 diabetes was accompanied by positive dynamics in the levels of SFAA. A decrease in the levels of methionine, valine, cysteine in patients of both study groups was found. Attention is drawn to the more pronounced positive dynamics in the levels of such amino acids as tryptophan, tyrosine, phenylalanine, asparagine $(p<0.01)$, mainly in patients of group II. Conclusions. In patients with CP and type 2 diabetes, DB of mainly III and II degrees were found, which is accompanied by a violation of the levels of SFAA in these patients. Complex therapy with Bacillus coagulans and vitamin $B_{9}, B_{12}$ in combination with $B$. infantis 35624 in patients with $\mathrm{CP}$ and type 2 diabetes is an effective means of normalizing of $\mathrm{DB}$, which, in turn, is accompanied by positive dynamics in the levels of SFAA (decrease of methionine, valine, cysteine and increased levels of tryptophan, tyrosine, phenylalanine).
\end{abstract}

Keywords: chronic pancreatitis, diabetes mellitus type 2, dysbiosis, serum free amino acids, treatment.

\section{Вступ}

Дисбіоз кишечника часто виникає при захворюваннях органів травлення, у тому числі і при хронічному панкреатиті (ХП). Клініка ХП із супутнім дисбіозом товстої кишки (ДТК) ускладнюється посиленням синдрому кишкової диспепсії (метеоризм, бурчання, здуття живота, дискомфорт, відчуття тяжкості і розпирання, нестабільний стілець), синдрому порушення травлення (стеаторея, порушення всмоктування жиророзчинних вітамінів D і K, порушення водно-електролітного балансу), астено-вегетативного синдрому, зумовленого гіпо- й авітамінозом, диспротеїнемією, інтоксикацією [1, 2].

Сумація та потенціювання несприятливих факторів ризику та дія етіологічних чинників сприяють зростанню захворюваності на панкреатит (ХП), а також прогресуванню зовнішньосекреторної недостатності (3СН) підшлункової залози (ПЗ), розвитку мальдигестії, мальабсорбції, трофологічної недостатності хворих із порушенням усіх видів обміну [3-5].

Цукровий діабет - особливе захворювання, на тлі якого відзначається зростання коморбідних патологій. При ЦД порушуються всі види обміну речовин, у результаті чого так чи інакше уражуються всі органи і системи організму, у тому числі й система органів травлення (стравохід, шлунок, кишечник, печінка, підшлункова залоза) [6].

Проведені дослідження ланок патогенезу ХП за умов ізольованого перебігу та різноманітної коморбідності доводять важливу роль системного запалення, дисбалансу про- та протизапальних цитокінів, чинників протеїназоінгібіторної системи, порушення оксидантно-антиоксидантного гомеостазу, що сприяє розвитку ендогенної інтоксикації, яка зростає на тлі супровідного ДТК із формуванням порушень ліпідного та білкового спектра крові, дисбалансу білкових та вуглеводно-білкових компонентів, амінокислотних резервів організму [3-5]. 
Отже, дослідження вітамінного забезпечення організму при дисбіозі кишечника у хворих на ХП, особливо при його поєднанні із ЦД 2-го типу, є актуальним питанням у хворих із коморбідними станами.

Мета дослідження - дослідити ефективність різних схем корекції ДТК та її вплив на динаміку вільних амінокислот сироватки крові (BAKCK) у хворих на ХП та ЦД 2-го типу.

Наукове дослідження $є$ фррагментом держбюджетної теми кафедри хірургічних хвороб та кафредри пропедевтики внутрішніх хвороб медичного фракультету ДВНЗ УжНУ № 851 «Механізми фрормування ускладнень при захворюваннях печінки та підшлункової залози, методи їх лікування та профрілактики» (номер державної реєстрації: 0115U001103), а також наукової теми кафедри пропедевтики внутрішніх хвороб «Поліморбідна патологія при захворюваннях органів травлення, особливості патогенезу, можливості корекції» (номер державної реєстрації 0118U004365).

\section{Матеріали та методи}

Під нашим спостереженням на стаціонарному лікуванні в ендокринологічному та гастроентерологічному КНП ЗОКЛ ім. А. Новака 30Р, у хірургічному відділенні № 1 Мукачівської центральної районної лікарні ім. Святого Мартина, а також на амбулаторно-диспансерному спостереженні в дільничного сімейного лікаря за місцем проживання перебувало 82 хворих на ХП та ЦД 2-го типу.

Серед обстежених чоловіків було $49(59,8 \%)$, жінок - 33 (40,2\%). Середній вік становив $49,7 \pm 5,3$ року. До контрольної групи увійшло 20 практично здорових осіб (11 чоловіків $(55,0 \%), 9$ жінок $(45,0 \%))$. Середній вік становив 45,2 $\pm 5,1$ року.

Усі дослідження виконувались за згодою пацієнтів, а методика їх проведення відповідала Гельсінській декларації прав людини 1975 р. та її перегляду 1983 р., Конвенції Ради Європи про права людини і біомедицину та законодавству України.

Усім обстеженим пацієнтам проведено загальноклінічні, антропометричні, інструментальні та лабораторні методи дослідження. Для верифікації діагнозу звертали увагу на характер скарг, анамнез захворювання. Усім пацієнтам виконано ультразвукове дослідження органів черевної порожнини за загальноприйнятою методикою. У сироватці крові проведено стандартні загальні та біохімічні дослідження 3 акцентом на показники вуглеводного обміну (глюкози, інсуліну, глікозильованого гемоглобіну (HbA1c,\%), тесту на порушення толерантності до глюкози).

Дослідження якісного і кількісного складу мікрофрлори товстої кишки (МTK) до та після проведеного лікування проводили методом посіву десятикратних розведень $\left(10^{-1}-10^{-9}\right)$ фекалій на стандартний набір селективних і диференціально-діагностичних поживних середовищ для виділення аеробних і анаеробних мікроорганізмів. Ступінь дисбіозу товстої кишки оцінювали за класифікацією Куваєвої І.Б., Ладодо К.С. (1991).

Кількісне визначення рівня ВАКСК проводили за методом обернено-фразової високоефективної рідинної хроматографії в ізократичному режимі елюювання з електрохімічним детектуванням (І.Н. Краснова та ін., 2000). Для хроматографії використовували рідинний хроматографр («Міліхром», Росія) з електрохімічним детектором [7].

Діагноз ХП встановлювали відповідно до марсельсько-римських критеріїв (1989) із доповненнями Я.С. Циммермана (1995) та уточненнями MKX-10. Для вивчення зовнішньосекреторної функції (ЗСН) ПЗ проводилось копрологічне дослідження, визначався рівень амілази сироватки крові та фекальної еласта-

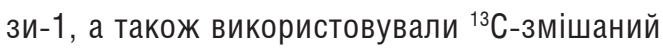

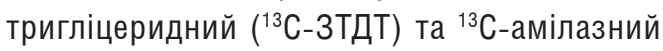
дихальні тести $\left({ }^{13} \mathrm{C}-\mathrm{AДТ}\right)$.

Надання медичної допомоги обстеженим хворим на ЦД проводили згідно з клінічними протоколами М03 України та локальними протоколами. Діагноз ЦД 2-го типу встановлено згідно з рекомендаціями IDF (2005), а також з урахуванням критеріїв уніфрікованого клінічного протоколу (наказ М03 України від 21.12.2012 № 1118) [8, 9]. Ступінь важкості ЦД 2-го типу оцінювали за рівнем HbA1c (норма - до 6,0\%).

На тлі базисної терапії, що спрямована на нормалізацію рівня цукру в сироватці крові (переважно метформін в індивідуальному дозуванні), а також проявів 3СН ПЗ (індивідуально підібрана доза поліферментних препаратів, інгібітори протонної помпи, селективні спазмолітики), для корекції ДТК хворим призначено ципрофлоксацин по 500 мг 2 рази на добу протягом 7 днів. Хворих на ХП та ЦД 2-го типу розподілено на 2 групи залежно від методу корекції ДТК: до I групи увійшло 42 хворих на ХП та ЦД 2-го типу, що отримували 
комплексний препарат Лактовіт форте (фрірми «Мілі Хелскере Лімітед», Велика Британія), до складу якого входять фолієва кислота (1,5 мг), вітамін $\mathrm{B}_{12}$ (15 мкг), Lactic Acid Bacillus (Bacillus coagulans (Lb. sporogenes)) (120 мільйонів спор) по 2 капсули 2 рази на добу протягом 2 місяців; ІІ групу становили 40 хворих на ХП та ЦД 2-го типу, які додатково до Лактовіт форте отримували препарат Bifidobacterium infantis (B. infantis) 35624 - Альфлорекс (фірми Biocodex) по 1 капсулі 1 раз на добу протягом 2 місяців.

Аналіз і обробка результатів обстеження хворих здійснювалися за допомогою комп'ютерної програми STATISTICA 10.0 (фрірми StatSoft Inc, USA) з використанням параметричних та непараметричних методів оцінки отриманих результатів.

\section{Результати та обговорення}

За даними результатів клініко-лабораторних та інструментальних методів обстеження у всіх обстежених нами хворих діагностовано ХП, що проявлялось порушенням ЗСН ПЗ (за даними копрологічного дослідження, змін рівня амілази в сироватці крові, фекальної еластази-1, даних ${ }^{13} \mathrm{C}$-ЗТДТ та ${ }^{13} \mathrm{C}-\mathrm{AДТ).} \mathrm{Також} \mathrm{у} \mathrm{всіх} \mathrm{об-}$ стежених нами пацієнтів встановлено ЦД 2-го типу переважно легкого та середнього ступеня важкості, а саме відсутність гіпоглікемічних реакцій (рівень глюкози в крові натще - не вище ніж 8,5 ммоль/л, після їди - не вище ніж 10 ммоль/л, показник HbA1c - не перевищував 7,0\%).

Аналіз даних мікробіологічного дослідження фекалій в обстежених хворих на ХП та ЦД 2-го типу до лікування вказує на виражені зміни в кількісному та якісному складі МТК.

\section{Таблиця 1}

Динаміка вираженості ДТК у хворих на ХП та ЦД 2-го типу на тлі комплексного лікування

Ступінь ДТК Обстежені хворі на ХП та ЦД 2-го типу

\begin{tabular}{|c|c|c|c|c|}
\hline & \multicolumn{2}{|l|}{ I група (n=42) } & \multicolumn{2}{|l|}{ II група (n=40) } \\
\hline & до лікування & після лікування & до лікування & після лікування \\
\hline 0 ступінь & - & $33,3 \%$ & - & $52,5 \%$ * \\
\hline І ступінь & $19,0 \%$ & $42,9 \%$ * & $15,0 \%$ & $30,0 \%$ \\
\hline II ступінь & $28,6 \%$ & $23,8 \%$ & $35,0 \%$ & $17, \%$ \\
\hline III ступінь & $52,4 \%$ & - & $50,0 \%$ & - \\
\hline
\end{tabular}

Примітка: показники у хворих I групи після лікування достовірно відрізняються від таких показників у хворих II групи: * $-p<0,05$.
У всіх хворих до лікування встановлено зниження рівня представників анаеробної флори: біфідобактерій — нижче ніж $10^{7}$, лактобактерій - нижче ніж $10^{6}$, що супроводжувалось підвищенням кількості патогенної мікрофлори в товстій кишці: підвищення кількості Klebsiella

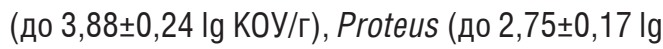
КОУ/г), Clostridium (до 5,34 $\pm 0,11 \mathrm{lg} \mathrm{K0У/г),}$

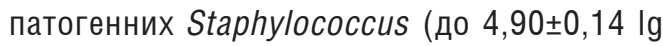
КОУ/г), грибів роду Candida (до 4,14 $\pm 0,18 \mathrm{lg}$ $\mathrm{KOV} / г)$.

Призначена терапія виявилась ефективною в обох групах обстежених хворих на ХП та ЦД 2-го типу на вираженість проявів ДТК. Поряд із цим слід відзначити, що одночасне використання комбінованого пробіотика, до складу якого входять Bacillus coagulans та вітаміни $\mathrm{B}_{9}$ і $\mathrm{B}_{12}$, у поєднанні з препаратом B. infantis 35624 виявилось більш ефективним, про що свідчить збільшення на 19,2\% кількості пацієнтів у II групі, у яких після курсу проведеного лікування не встановлено явища ДТК $(p<0,05)$. Також серед обстежених II групи на 6,3\% рідше визначали після лікування ДТК II ступеня (табл. 1).

Подальший аналіз отриманих даних вказує на порушення рівнів BAKCK у хворих на ХП та ЦД 2-го типу. Виявлені зміни до проведеного комплексного лікування характеризувались переважним статистично достовірним зменшенням рівнів триптофану, тирозину, фенілаланіну, аспарагіну $(p<0,01)$, а також аргініну $(p<0,05)$ та лізину в обох групах обстежених пацієнтів. Паралельно визначали статистично достовірне збільшення показника метіоніну $(p<0,01)$, валіну, цистеїну, орнітину $(p<0,05)$ та незначне збільшення показника ізолейцину, лейцину (табл. 2).

Нормалізація мікрофлори товстої кишки у хворих на ХП та ЦД 2-го типу супроводжувалась позитивною динамікою в рівнях ВАКСК. У хворих I та II груп майже в однаковому ступені вираженості встановлено зменшення показників таких амінокислот, як метіонін

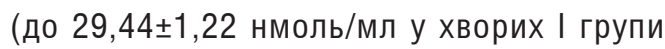

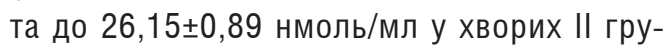
пи - $p<0,01$ ), валін (до 222,14 $\pm 5,23$ нмоль/мл у хворих I групи та до 218,16 6 ,77 нмоль/мл у хворих II групи - $p<0,05)$, цистеїн (до 181,12ะ8,26 нмоль/мл у хворих I групи та до 180,55ะ6,32 нмоль/мл у хворих II групи $p<0,05)$.

Звертає увагу більш виражена позитивна динаміка в рівнях таких амінокислот, як триптофан, тирозин, фенілаланін, аспарагін 
( $<<0,01)$, переважно у хворих II групи, які до комплексного препарату Bacillus coagulans та вітамінів $\mathrm{B}_{9}, \mathrm{~B}_{12}$ додатково отримували препарат B. infantis 35624.

Таким чином, проведені нами дослідження дозволяють встановити, що у хворих на ХП та ЦД 2-го типу визначаються виражені зміни в мікробному складі товстої кишки, а саме ДТК переважно III та II ступенів. Комплексна терапія із використанням одночасно двох пробіотичних препаратів $\epsilon$ ефрективним засобом для нормалізації мікробного пейзажу товстої кишки, що також супроводжується нормалізацією ВАКСК.

Проведені численні експериментальні дослідження продемонстрували, що пероральний прийом Bifidobacterium infantis збільшує рівень триптосрану - попередника серотоніну у плазмі щурів, що вказує на те, що штам може мати потенціал як антидепресант $[10,11]$. Результати наших досліджень також вказують на високу ефективність комплексного використання B. infantis 35624 в поєднанні з Bacillus coagulans та вітамінами $B_{9}$ i $B_{12}$ не тільки на стан мікрофрлори товстої кишки, а й на рівні ВАКСК у хворих на ХП та ЦД 2-го типу. Проте потрібні подальші дослідження для визначення більш чітких терапевтичних можливостей у хворих із коморбідною патологією.

\section{Висновки}

На підставі наведеного вище можна зробити такі висновки:

1. У хворих на ХП та ЦД 2-го типу встановлено ДТК переважно III та II ступенів, що супроводжується порушенням рівнів ВАКСК у цих пацієнтів.

2. Комплексна терапія із використанням препарату Bacillus coagulans та вітамінів $\mathrm{B}_{9}$ і $\mathrm{B}_{12}$ у поєднанні 3 B. infantis 35624 у хворих на ХП та ЦД 2-го типу $є$ ефрективним засобом для нормалізації ДТК, що, у свою чергу, супроводжується позитивною динамікою в рівнях ВАКСК (зменшенням показника метіоніну, валіну, цистеїну та збільшенням рівня триптосрану, тирозину, фенілаланіну).

\section{Таблиця 2}

Динаміка рівнів ВАКСК в обстежених хворих на ХП та ЦД 2-го типу на тлі лікування і контрольної групи

\begin{tabular}{|c|c|c|c|}
\hline \multirow{3}{*}{$\begin{array}{l}\text { Контрольна } \\
\text { група }(\mathrm{n}=20) \\
\text { Амінокислоти, } \\
\text { нмоль/мл }\end{array}$} & & \multicolumn{2}{|c|}{$\begin{array}{l}\text { Обстежені хворі на ХП } \\
\text { та ЦД 2-го типу }\end{array}$} \\
\hline & & I група (n=42) & II група $(\mathrm{n}=40)$ \\
\hline & & \multicolumn{2}{|l|}{$M \pm m$} \\
\hline Цистеїн (Cys) & до лікування & $241,23 \pm 7,57^{\star}$ & $248,48 \pm 5,89 *$ \\
\hline $176,13 \pm 7,11$ & після лікування & $181,12 \pm 8,26^{+}$ & $180,55 \pm 6,32^{+}$ \\
\hline Орнітин (Orn) & до лікування & $288,16 \pm 7,06^{\star}$ & $292,15 \pm 8,15^{\star}$ \\
\hline $239,44 \pm 6,71$ & після лікування & $265,12 \pm 8,00$ & $244,13 \pm 8,23^{+}$ \\
\hline Лізин (Lys) & до лікування & $261,11 \pm 5,05$ & $257,01 \pm 7,89$ \\
\hline $272,15 \pm 7,11$ & після лікування & $271,14 \pm 7,19$ & $270,17 \pm 5,01$ \\
\hline Гістидин (His) & до лікування & $87,15 \pm 3,12$ & $87,21 \pm 2,15$ \\
\hline $89,85 \pm 3,62$ & після лікування & $91,23 \pm 2,88$ & $90,21 \pm 1,77$ \\
\hline Аргінін (Arg) & до лікування & $74,17 \pm 3,15^{\star}$ & $72,56 \pm 3,11^{*}$ \\
\hline $96,12 \pm 2,23$ & після лікування & $87,15 \pm 2,22$ & $96,11 \pm 3,04^{+}$ \\
\hline Аспарагін (Asp) & до лікування & $4,21 \pm 0,42^{* *}$ & $4,18 \pm 0,27^{\star \star}$ \\
\hline $8,89 \pm 0,31$ & після лікування & $6,35 \pm 0,55^{+}$ & $7,34 \pm 0,41^{++, \Lambda}$ \\
\hline Серин (Ser) & до лікування & $110,70 \pm 7,01$ & $109,56 \pm 7,12$ \\
\hline $120,14 \pm 4,17$ & після лікування & $115,12 \pm 2,18$ & $117,13 \pm 5,09$ \\
\hline Гліцин (Gly) & до лікування & $280,10 \pm 8,05$ & $278,12 \pm 7,45$ \\
\hline $277,90 \pm 5,12$ & після лікування & $277,15 \pm 6,22$ & $279,45 \pm 6,09$ \\
\hline Глутамін (Gln) & до лікування & $521,47 \pm 7,16$ & $525,23 \pm 7,56$ \\
\hline $510,17 \pm 5,62$ & після лікування & $515,50 \pm 5,69$ & $512,78 \pm 6,22$ \\
\hline Треонін (Thr) & до лікування & $147,29 \pm 4,21$ & $146,75 \pm 5,44$ \\
\hline $167,15 \pm 6,08$ & після лікування & $161,11 \pm 5,15$ & $169,79 \pm 4,19$ \\
\hline Аланін (Ala) & до лікування & $396,10 \pm 6,80$ & $394,20 \pm 7,00$ \\
\hline $418,19 \pm 7,06$ & після лікування & $413,67 \pm 5,77$ & $419,00 \pm 5,15$ \\
\hline Пролін (Pro) & до лікування & $185,06 \pm 4,24^{\star}$ & $187,22 \pm 8,09^{\star}$ \\
\hline $147,15 \pm 5,60$ & після лікування & $166,12 \pm 8,14$ & $149,23 \pm 5,77^{+}$ \\
\hline Тирозин (Tyr) & до лікування & $42,11 \pm 2,14^{\star *}$ & $40,17 \pm 1,89^{\star *}$ \\
\hline $64,60 \pm 1,53$ & після лікування & $48,26 \pm 2,77$ & $60,15 \pm 1,99^{++,} \wedge$ \\
\hline Триптофан (Trp) & до лікування & $23,17 \pm 1,41^{\star *}$ & $24,15 \pm 1,88^{\star \star}$ \\
\hline $58,54 \pm 1,13$ & після лікування & $34,26 \pm 1,70$ & $54,13 \pm 2,10^{++, \wedge}$ \\
\hline Метіонін (Met) & до лікування & $48,50 \pm 1,14^{\star *}$ & $49,51 \pm 1,07^{\star *}$ \\
\hline $25,17 \pm 0,88$ & після лікування & $29,44 \pm 1,22^{++}$ & $26,15 \pm 0,89^{++}$ \\
\hline Валін (Val) & до лікування & $268,59 \pm 7,22^{*}$ & $274,16 \pm 6,12^{\star}$ \\
\hline $219,24 \pm 8,17$ & після лікування & $222,14 \pm 5,23^{+}$ & $218,16 \pm 6,77^{+}$ \\
\hline Фенілаланін (Phe) & до лікування & $46,32 \pm 2,67^{\star *}$ & $45,22 \pm 2,89 * \star$ \\
\hline $83,22 \pm 3,55$ & після лікування & $55,28 \pm 2,07$ & $78,17 \pm 8,13^{++, \wedge}$ \\
\hline Лейцин (Leu) & до лікування & $134,21 \pm 3,15$ & $132,71 \pm 6,78$ \\
\hline $125,16 \pm 5,23$ & після лікування & $126,11 \pm 4,26$ & $124,15 \pm 5,88$ \\
\hline Ізолейцин (ILeu) & до лікування & $145,10 \pm 6,22$ & $147,28 \pm 4,50$ \\
\hline $119,18 \pm 5,67$ & після лікування & $122,10 \pm 4,55$ & $119,89 \pm 7,11$ \\
\hline
\end{tabular}

Примітки: показники у хворих I та // груп до лікування достовірно відрізняються від таких показників контрольної групи: * $-p<0,05 ;{ }^{*}$ * $-p<0,01$; різниця між показниками у хворих у межах груп після лікування достовірна: ${ }^{+}-p<0,05 ;{ }^{++}-p<0,01$; різниця між показниками у хворих I та I/ груп після лікування достовірна: ^ $-p<0,05$. 


\section{Список використаної літератури}

1. Kocaba Yu.Ya., Babinec L.S. Topical aspects of the use of probiotics in colonic dysbiosis // Family medicine. - 2018. - Vol. 4 (78). - P. 8587. (in Ukrainian)

2. Larin A.S., Tkach S.M. Phatogenetocheskaja rol kisechnogo disbioza v razvitii ozhirenia, insulinorezistentnosti I sacharnogo diabeta 2 tipa. Health of Ukraine // Thematic number. Gastroenterology. Hepatology. Coloproctology. - 2016. - Vol. 2 (40). - P. 20-21. (in Russian)

3. Huhlina O.S., Dudka I.V., Dudka T.V., Smandich V.S. Clinical efficacy of Antral@ in patients with chronic pancreatitis // Health of Ukraine. 2020. - Vol. 3. - P. 17. (in Ukrainian)

4. Raksha N.G., Halenova T.I., Vovk T.B., Sukhodolia S.A., Beregova T.V., Ostapchenko L.I. Proteolitic imbalance as a key factor of the development of chronic pancreatitis with and without type 1 diabetes mellitus // Visnik problem biologii i medicine. - 2019. — Vol. 3 (152). P. 186-191. (in Ukrainian) DOI 10.29254/2077-4214-2019-3-152-186-191.

5. Hristich T.M., Hontsariuk D.O. Etiological factors which from the chronical pancreatitis // Zdobutki klinichnoji I eksperimentalnoji medicine. 2018. - Vol. 3. - P. 20-27. (in Ukrainian) DOI 10.11603/1811-2471.2018.v0.i3.9221

6. Fadejenko G.D., Chernishov V.A. Defeat of the gastroduodenal area in patients with diabetes mellitus: clinical and population aspects // Medicine of Ukraine. - 2011. - Vol. 7 (153). - P. 48-50. (Ukranian)

7. Krasnova I.N., Karpova L.A., Cherkas Yu.V. Opredelenije aminokislot v sivorotke krovi cheloveka metodom obrachenno-fazovoj visokoeffektivnoj zhidkostnoj chromatografii v rezhime izokraticheskogo eljuirovanija // Zhurnal analiticheskoj chimii. — 2000. — Vol. 55 (1). P. 66-74. (in Russian)

8. Hobzej M.K., Guljchij M.V., Stepanenko A.V. et al. Type 2 Diabetes Mellitus. Unified clinical protocol for primary and secondary (specialized) medical care. - Kijiv, 2012. - 118 p. (in Ukrainian). http://ukrgastro.com.ua/klinichni-protokoli-ta-nastanovi/

9. Hobzej M.K., Matyuha L.F., Netjazhenko V.Z. et al. Type 2 Diabetes Mellitus. Adapted clinical guideline based on evidence. — Kijiv, 2012. 343 p. (in Ukrainian). http://ukrgastro.com.ua/klinichni-protokoli-ta-nastanovi/

10. Caroline P., Brietzke E., Rosenblat J.D. et al. Probiotics for the treatment of depressive symptoms: An anti-inflammatory mechanism? // Brain . Behavior and Immunity. — 2018. Jul 18. pii: S0889-1591(18)30304-0. DOI: 10.1016/i.bbi.2018.07.006.

11. Desbonnet L., Garrett L., Clarke G., Kiely B., Cryan J.F., Dinan T.G. Effects of the probiotic Bifidobacterium infantis in the maternal separation model of depression // Neuroscience. — 2010. — Vol. 170 (4). - P. 1179-1188. DOI: 10.1016/j.neuroscience.2010.08.005. 